\title{
Acta
Biochimica
Polonica
}

Vol. 49 No. 1/2002

$59-65$

QUARTERLY

\section{Dual effect of 2-methoxyestradiol on cell cycle events in human osteosarcoma 143B cells ${ }^{\star}$}

\author{
Justyna Gołębiewska ${ }^{1}$, Piotr Rozwadowski ${ }^{1}$, Jan Henryk Spodnik ${ }^{2}$, Narcyz Knap ${ }^{3}$, \\ Takashi Wakabayashi ${ }^{3}$ and Michał Woźniak ${ }^{3 凶}$ \\ ${ }^{1}$ Student Research Group of the Department of Medical Chemistry, Medical University of \\ Gdańsk, Gdańsk, Poland; ${ }^{2}$ Department of Anatomy and Neurobiology, Medical University of \\ Gdańsk, Gdańsk, Poland; ${ }^{3}$ Department of Medical Chemistry, Medical University of Gdańsk, \\ Gdańsk, Poland
}

Received: 13 November, 2001; revised: 9 January, 2002; accepted: 7 February, 2002

Key words: 2-methoxyestradiol, cell cycle, apoptosis, osteosarcoma 143B cells

\begin{abstract}
We have demonstrated for the first time that the steroid metabolite, 2-methoxyestradiol (2-ME) is a powerful growth inhibitor of human osteosarcoma $143 \mathrm{~B}$ cell line by pleiotropic mechanisms involving cell cycle arrest at two different points and apoptosis.

The ability of 2-ME to inhibit cell cycle at the respective points has been found concentration dependent. $1 \mu \mathrm{M} 2 \mathrm{ME}$ inhibited cell cycle at $\mathrm{G}_{1}$ phase while $10 \mu \mathrm{M} 2-\mathrm{ME}$ caused $\mathrm{G}_{2} / \mathrm{M}$ cell cycle arrest. As a natural estrogen metabolite 2-ME is expected to perturb the stability of microtubules (MT) in vivo analogously to Taxol - the MT binding anticancer agent. Contrary to 2-ME, Taxol induced accumulation of osteosarcoma cells in $\mathrm{G}_{2} / \mathrm{M}$ phase of cell cycle only. The presented data strongly suggest two different mechanisms of cytotoxic action of 2-ME at the level of a single cell.
\end{abstract}

Methoxyestradiol (2-ME) is a natural estrogenic metabolite formed by hydroxylation of estradiol followed by its O-methylation in the liver [1]. Previous studies showed that this estrogen has a cytotoxic effect on various proliferating cells in vitro [2-9] and suppresses certain murine tumors in vivo [10-12]. 2-ME is also well known as an inhibitor of microtubule dynamics causing mitotic arrest $[13,14]$ followed by apoptosis [15]. The exact mechanism by which 2-ME inhibits target cell proliferation is still practically unknown. One of the postulated mechanisms for cytotoxic effect of 2-ME is its interference with the stability of

\footnotetext{
${ }^{\star}$ Presented at the Polish Japanese Free Radical Forum, 2001.

${ }^{\bowtie}$ Prof. Michał Woźniak, Department of Medical Chemistry, Medical University of Gdańsk, 80-211 Gdańsk, Dębinki 1, Poland; tel. (0 58) 349 1450; fax. (0 58) 349 1456; e-mail: mwozniak@amg.gda.pl Abbreviations: 2-ME, 2-methoxyestradiol; MT, microtubules; $\mathrm{Me}_{2} \mathrm{SO}$, dimethylsulfoxide; DMEM, Dulbecco modified Eagle's medium; PBS, phosphate-buffered saline; PI, propidium iodide.
} 
microtubules and the subsequent cell growth arrest in $\mathrm{G}_{2} / \mathrm{M}$ phase of the cell cycle [13, 14]. By contrast, quite dissimilar effects of 2-ME on cell-cycle distribution of breast cancer cells and prostate cancer cells have been observed. Treatment of breast cancer cells with 2-ME results in accumulation of cells in the $\mathrm{G}_{1}$ phase [15] whereas prostate cancer cells show a marked accumulation of cells in the $\mathrm{G}_{2} / \mathrm{M}$ phase [12, 16].

In this report we provide evidence for 2-ME concentration dependent mechanisms of perturbation of the cell cycle machinery at two different points of the osteosarcoma 143B cells.

\section{MATERIALS AND METHODS}

Reagents. Methoxyestradiol (2-ME), dimethyl sulfoxide $\left(\mathrm{Me}_{2} \mathrm{SO}\right)$ and Taxol were purchased from Sigma (St. Louis, MO, U.S.A.). Propidium iodide (PI) was from Molecular Probes (Eugene, OR, U.S.A.). DMEM (Dulbecco modified Eagle's medium) was from Nissui (Tokyo, Japan) and anti-acetylated tubulin antibodies (clone No. 6-11 B-1) were from Sigma (St. Louis, MO, U.S.A.).

Cell culture. 143B (TK[-]) human osteosarcoma cells $\left(\rho^{+}\right)$(ATCC CRL-8303) were cultured at $37^{\circ} \mathrm{C}$ in a humidified atmosphere with $5 \% \mathrm{CO}_{2}$ in Dulbecco's modified Eagle's medium containing $1 \mathrm{mM}$ pyruvate, supplemented with $10 \%$ fetal bovine serum and $50 \mu \mathrm{g} / \mathrm{ml}$ kanamycin.

Cell cycle analysis. This was performed by flow cytometry, using nuclei labeled essentially according to Watabe et al. [17]. Cells were cultured on a $5 \mathrm{~cm}$ dish, harvested and washed with phosphate-buffered saline (PBS). Then DNA was stained with $500 \mu \mathrm{l}$ of a PI solution containing $50 \mu \mathrm{g} / \mathrm{ml}$ of propidium iodide, $0.1 \%$ sodium citrate, $0.2 \%$ Nonidet $\mathrm{P}-40$, supplemented with RNase $(0.25 \mathrm{mg} / \mathrm{ml})$ for $30 \mathrm{~min}$ at $4^{\circ} \mathrm{C}$ in the dark and then for $15 \mathrm{~min}$ at $37^{\circ} \mathrm{C}$ followed by flow cytometric analysis using a Coulter Epics XL flow cytometer
(Coulter Corp., Miami, FL, U.S.A.). Cell-cycle distribution as measured by DNA content was analyzed for 10000 cells for each culture. The relative proportion of cells in the $G_{1}, S$ and $\mathrm{G}_{2} / \mathrm{M}$ cell cycle phases were estimated by compartment analysis of DNA fluorescence using cell-cycle analysis software. Low-molecular mass DNA fluorescence was indicative of apoptotic cells. Two independent experiments were done in triplicate.

Caspase 3 (Apopain) activity assay. Cells were grown in $10 \mathrm{~cm}$ culture dishes. Caspase 3 activity was determined by Fluor Ace Apopain Assay Kit (Bio-Rad Laboratories, U.S.A.). Activity was monitored using the fluorogenic peptide substrate carbobenzoxy-Asp-Glu-Val7-amino-4-trifluoromethyl coumarin (2-DEVDAFC) [18]. Caspase 3 enzymatically cleaves the AFC from the peptide and releases free $\mathrm{AFC}$, which then produces a blue-green fluorescence detectable at $500-550 \mathrm{~nm}$ with Bio-Rad VersaFluor Fluorometer. All procedures were performed following the manufacturer's instructions. Caspase 3 units were calculated as follows: $\Delta \mathrm{F} / \mathrm{min} \times$ (calibration curve slope $)^{-1} \times 1000$. Cells were exposed to $1 \mu \mathrm{M} 2-\mathrm{ME}$ for $12 \mathrm{~h}$ and then cytosolic activity of caspase 3 was detected fluorometrically for the period of $3 \mathrm{~h}$.

Visualization of acetylated microtubules by confocal microscopy. Cells were permeabilized with $0.1 \%$ Triton X-100 in PBS for 10 min at room temperature, then blocked with $1 \%$ BSA in PBS, and incubated with monoclonal antibodies specific against acetylated tubulin (clone No. 6-11 B-1, Sigma) diluted 250-fold with blocking buffer, at room temperature for $1 \mathrm{~h}$. In the next step the cells were incubated with the secondary antibodies $(100 \times$ diluted) FITC-labelled goat anti-mouse IgG (Molecular Probes) at room temperature for $45 \mathrm{~min}$. Coverslips were placed on glass slides in a Perma Fluor mounting solution (Immunon, Pittsburgh, PA, U.S.A.) and analyzed by a BioRad Lasersharp MRC 1024 scanning confocal microscope [19]. 


\section{RESULTS}

Cells were treated for $24 \mathrm{~h}$ with 1 or $10 \mu \mathrm{M}$ 2-ME and then stained with anti-acetylated tubulin antibodies for confocal microscopic analysis. The results presented on Fig. 1 (A-C) revealed a decrease of acetylated tubulin in the treated cells. Increases of monomeric tubulin background, together with a dis- tinct decrease of the acetylated tubulin, can be easily detected (Fig. 1B, C). Cells underwent mitotic arrest after exposition to 2-ME, becoming significantly enlarged and multinucleated (Fig. 1B, C).

The above results confirmed the colchicine-like destabilizing effect of 2-ME on microtubules. 2-ME at $1 \mu \mathrm{M}$ final concentration induced a significant arrest at $\mathrm{G}_{1}$ phase
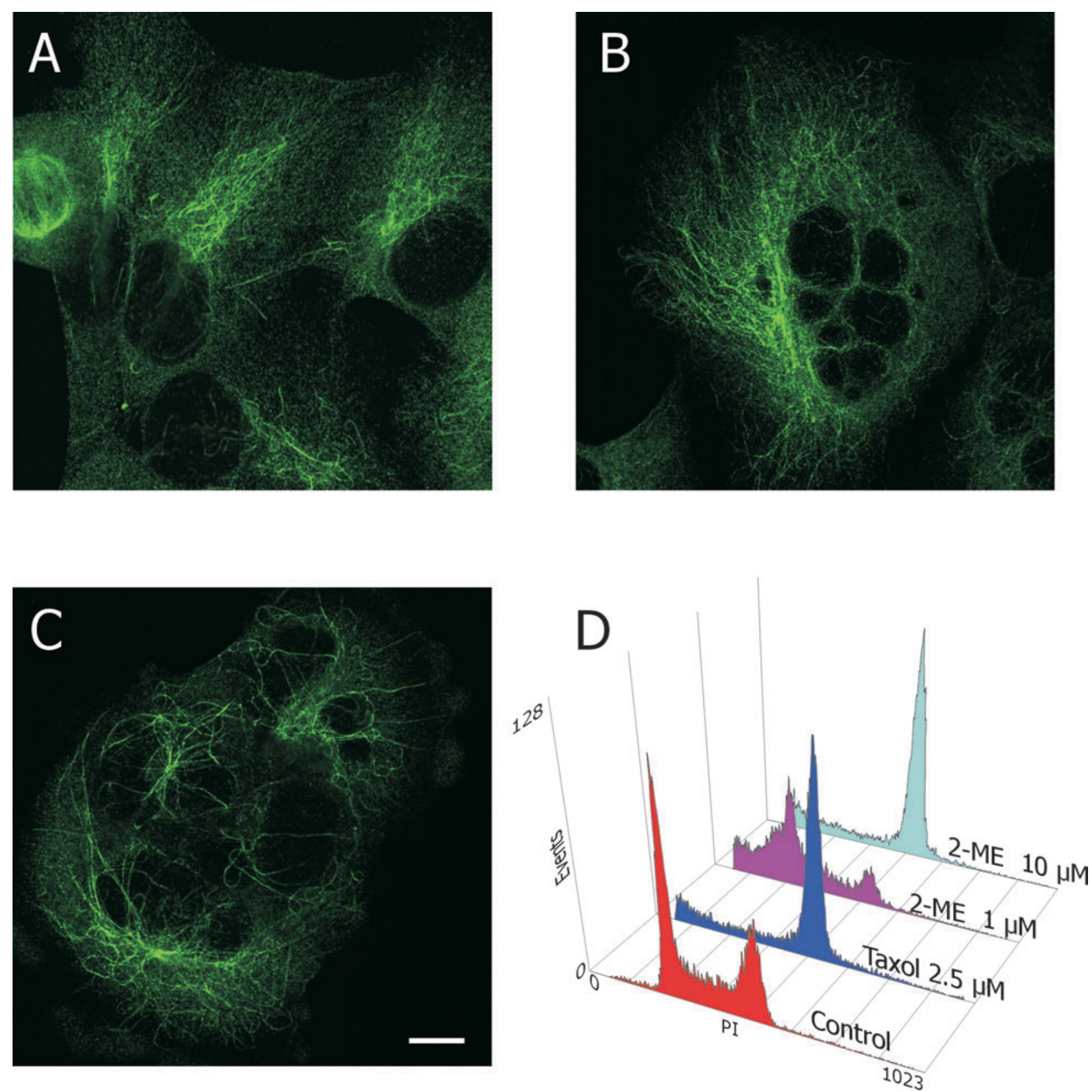

Figure 1. Changes of acetylated tubulin in osteosarcoma 143B cells after treatment with 2-methoxyestradiol for $24 \mathrm{~h}$.

A, Control; B, $1 \mu \mathrm{M}$ and C, $10 \mu \mathrm{M}$ 2-methoxyestradiol; scale bar $=10 \mu \mathrm{m}$; D, flow cytometric analysis of DNA fluorescence of PI-stained osteosarcoma 143B nuclei after $24 \mathrm{~h}$ of incubation with Taxol and 2-methoxyestradiol (2-ME). 
(about $33 \%$ of cells) in human osteosarcoma 143B cells (Fig. 1D). At $10 \mu \mathrm{M}$ concentration 2-ME caused a marked shift from $\mathrm{G}_{1}$ to $\mathrm{G}_{2} / \mathrm{M}$ phase indicative of the late cell cycle arrest (Fig. 1D). Taxol displayed the very same effect on the cell cycle as $10 \mu \mathrm{M}$ 2-ME (Fig. 1D). Analysis of apoptosis revealed marked apoptotic (sub $\mathrm{G}_{1}$ ) peak after $24 \mathrm{~h}$ of treatment with $10 \mu \mathrm{M}$ 2-ME (Fig. 1D). Cells treated with $1 \mu \mathrm{M}$ 2-ME displayed a different pattern of cell cycle phase distribution, $33 \%$ of $\mathrm{G}_{1} / \mathrm{G}_{0}$ being clearly visible (Fig. 2). The sub-G $\mathrm{G}_{1}$ popula-

\section{DISCUSSION}

The mechanism of 2-ME cytotoxic activity has been attributed to its ability to bind to the colchicine-binding site of tubulin resulting in altered stability of microtubules [20].

We demonstrated here that perturbation of microtubular stability by $10 \mu \mathrm{M} 2-\mathrm{ME}$ arrested asynchronously growing osteosarcoma cells at $\mathrm{G}_{2} / \mathrm{M}$ phase of the cell cycle. This arrest together with induction of apoptosis is a distinct mechanism of 2-ME action at its 10

\section{Cell cycle (143B cells, 24h)}

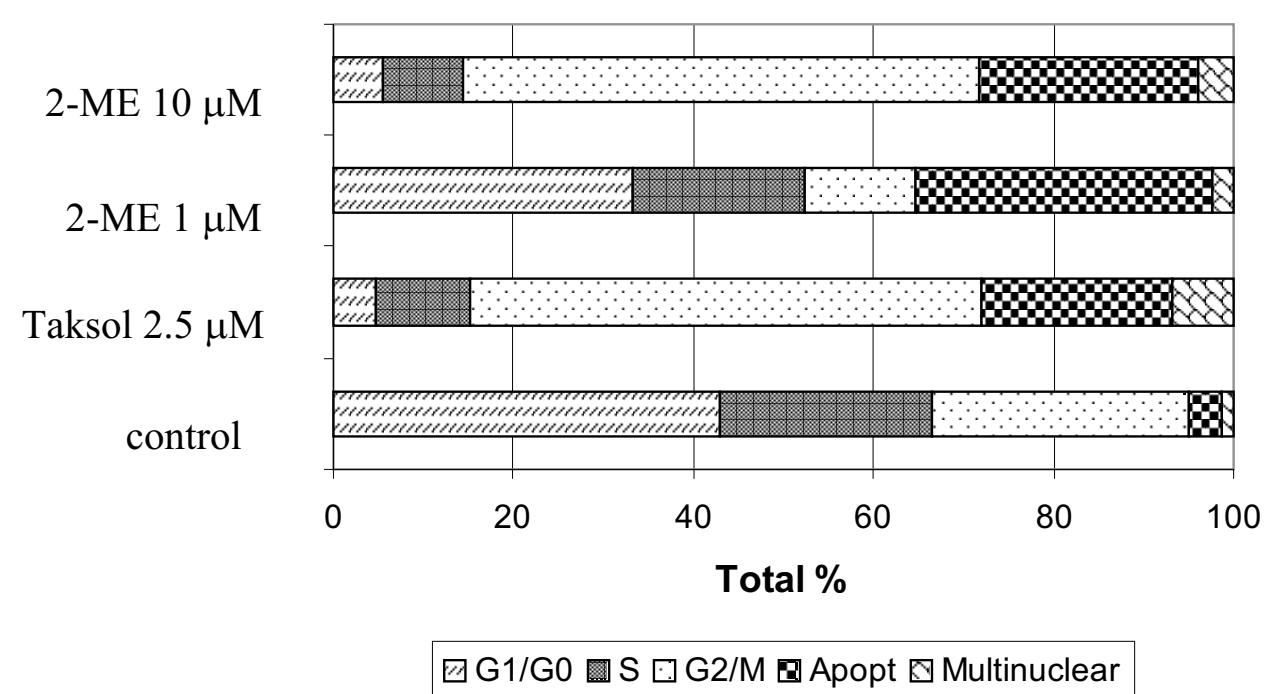

Figure 2. The effect of 2-ME and Taxol on cell cycle events in osteosarcoma 143B cell line.

Cellular subpopulations are presented as percentage of total cells number of culture. "Apopt", apoptosis, determined as sub- $\mathrm{G}_{1}$ population.

tion (treated as an apoptosis marker) reached as much as $33 \%$ of the total cell population of osteosarcoma cells. At $10 \mu \mathrm{M}$ concentration, accumulation of $58 \%$ of cells in $\mathrm{G}_{2} / \mathrm{M}$ phase was observed. Simultaneously, the $\mathrm{S}$ phase was depressed as compared with its level after treatment with $1 \mu \mathrm{M}$ 2-ME (Fig. 2). As on treatment with 2-ME the proportion of apoptotic cells was unexpectedly high, we decided to determine also caspase 3 activity. After treatment of cells for $12 \mathrm{~h}$ with $1 \mu \mathrm{M} 2-\mathrm{ME}$ the enzyme activity became significantly (over 5 -fold) elevated (not shown). $\mu \mathrm{M}$ concentration. Similar accumulation of prostate cancer and hepatoma cells in $\mathrm{G}_{2} / \mathrm{M}$ phase upon exposition to $5 \mu \mathrm{M}$ or $10 \mu \mathrm{M}$ 2-ME, respectively, has been also observed [12, 21]. Breast cancer cells, on the other hand, displayed a dissimilar cell cycle distribution pattern under the influence of 2-ME. When treated with submicromolar 2-ME the cells accumulated solely in $\mathrm{G}_{1}$ phase [15]. The breast cancer cell line, being more sensitive to 2-ME than the prostate cancer and hepatoma cells, was treated with lower concentration of this drug [15]. Therefore we decided to study 
the effect of 2-ME on osteosarcoma cells exposed to the final concentration of the drug as low as $1 \mu \mathrm{M}$.

At this 2-ME concentration we noticed a significant $G_{1}$ phase cell cycle arrest. Our study revealed a marked alteration of the level of acetylation of tubulin with a distinct decrease of the number of microtubules, which confirmed the colchicine-like destabilizing effect of 2-ME. Colchicine and vincristine act by inhibiting microtubule polymerization whereas Taxol causes formation of polymer with altered stability properties. The mechanism of 2-ME action appears to be more complex. This compound binds to both unpolymerized tubulin at the colchicine site and to the tubulin polymers at a less well-defined site [22-24].

In conclusion, our results demonstrate that 2-ME shows a pleiotropic effect on 143B osteosarcoma cell line in a concentration dependent manner.

Multiple discrete mechanisms are involved in the cytotoxic action of 2-ME, including $\mathrm{G}_{1}$ and $\mathrm{G}_{2} / \mathrm{M}$ cell cycle phase arrest, induction of caspase 3 activity and apoptosis. So far, the exact molecular mechanism of this process cannot be precisely described. 2-ME applied at $1 \mu \mathrm{M}$ concentration to $\mathrm{K} 562$ cells activated proapoptotic SAPK kinase [25].

The effect of 2-ME on cyclin B and cdc kinase activity may be considered a possible mechanism of cell cycle perturbation in osteosarcoma 143B cell line. Additional studies are required to elucidate the problem.

\section{R E F E R E N C E S}

1. Zhu, B.T. \& Conney, A.H. (1998) Is 2-methoxyestradiol an endogenous estrogen metabolite that inhibits mammary carcinogenesis? Cancer Res. 58, 2269-2277.

2. Yue, T.L., Wang, X., Louden, C.S., Gupta, S., Pillarisetti, K., Gu, J.L., Hart, T.K., Lysko,
P.G. \& Feuerstein, G.Z. (1997) 2-Methoxyestradiol, an endogenous estrogen metabolite, induces apoptosis in endothelial cells and inhibits angiogenesis: Possible role for stressactivated protein kinase signaling pathway and Fas expression. Mol. Pharmacol. 51, 951-962.

3. Shang, W., Konidari, I. \& Schomberg, D. W. (2001) 2-Methoxyestradiol, an endogenous estradiol metabolite, differentially inhibits granulosa and endothelial cell mitosis: A potential follicular antiangiogenic regulator. Biol. Reprod. 65, 622-627.

4. Dubey, R.K., Gillespie, D.G., Zacharia, L.C., Rosselli, M., Korzekwa, K.R., Fingerle, J. \& Jackson, E.K. (2000) Methoxyestradiols mediate the antimitogenic effects of estradiol on vascular smooth muscle cells via estrogen receptor-independent mechanisms. Biochem. Biophys. Res. Commun. 278, 27-33.

5. Banerjeei, S.K., Zoubine, M.N., Sarkar, D.K., Weston, A.P., Shah, J.H. \& Campbell, D.R. (2000) 2-Methoxyestradiol blocks estrogen-induced rat pituitary tumor growth and tumor angiogenesis: Possible role of vascular endothelial growth factor. Anticancer Res. 20, 2641-2645.

6. Wang, S.H., Myc, A., Koenig, R.J., Bretz, J.D., Arscott, P.L. \& Baker, J.R. (2000) 2-Methoxyestradiol, an endogenous estrogen metabolite, induces thyroid cell apoptosis. Mol. Cell Endocrinol. 165, 163-172.

7. Schumacher, G., Kataoka, M., Roth, J.A. \& Mukhopadhyay, T. (1999) Potent antitumor activity of 2-methoxyestradiol in human pancreatic cancer cell lines. Clin. Cancer Res. 5, 493-499.

8. Tsukamoto, A., Kaneko, Y., Yoshida, T., Han, K., Ichinose, M. \& Kimura, S. (1998) 2-Methoxyestradiol, an endogenous metabolite of estrogen, enhances apoptosis and beta-galactosidase expression in vascular en- 
dothelial cells. Biochem. Biophys. Res. Commun. 248, 9-12.

9. Mukhopadhyay, T. \& Roth, J.A. (1997) Induction of apoptosis in human lung cancer cells after wild-type p53 activation by methoxyestradiol. Oncogene 14, 379-384.

10. Klauber, N., Parangi, S., Flynn, E., Hamel, E. \& D'Amato, R.J. (1997) Inhibition of angiogenesis and breast cancer in mice by the microtubule inhibitors 2-methoxyestradiol and taxol. Cancer Res. 57, 81-86.

11. Fotsis, T., Zhang, Y., Pepper, M.S., Adlercreutz, H., Montesano, R., Nawroth, P.P. $\&$ Schweigerer, L. (1994) The endogenous oestrogen metabolite 2-methoxyoestradiol inhibits angiogenesis and suppresses tumour growth. Nature 368, 237-239.

12. Qadan, L.R., Perez-Stable, C.M., Anderson, C., D'Ippolito, G., Herron, A., Howard, G.A. \& Roos, B.A. (2001) 2-Methoxyestradiol induces G2/M arrest and apoptosis in prostate cancer. Biochem. Biophys. Res. Commun. 285, 1259 1266.

13. Brueggemeier, R.W., Bhat, A.S., Lovely, C.J., Coughenour, H.D., Joomprabutra, S., Weitzel, D.H., Vandre, D.D., Yusuf, F. \& Burak, W.E. (2001) 2-Methoxymethylestradiol: A new 2-methoxy estrogen analog that exhibits antiproliferative activity and alters tubulin dynamics. J. Steroid Biochem. Mol. Biol. 78, 145-156.

14. Ochi, T. \& Oda, T. (2001) Structure-effect relationship in the induction of mitotic phase-specific abnormality of centrosome integrity and multipolar spindles by steroidal estrogens and their derivatives in cultured mammalian cells. J. Steroid Biochem. Mol. Biol. 78, 113-122.

15. Schumacher, G. \& Neuhaus, P. (2001) The physiological estrogen metabolite 2-methoxyestradiol reduces tumor growth and induces apoptosis in human solid tumors. J. Cancer Res. Clin. Oncol. 127, 405-410.
16. Kumar, A.P., Garcia, G.E. \& Slaga, T.J. (2001) 2-Methoxyestradiol blocks cell-cycle progression at G(2)/M phase and inhibits growth of human prostate cancer cells. Mol. Carcinogen 31, 111-124.

17. Watabe, S., Wada, S., Saito, S., Matsunaga, S., Fusetani, N., Ozaki, H. \& Karaki, H. (1996) Cellular changes of rat embryonic fibroblasts by an actin-polymerization inhibitor, bistheonellide A, from a marine sponge. Cell Struct. Funct. 21, 199-212.

18. Nicholson, D.W., Ali, A., Thornberry, N.A., Vaillancourt, J.P., Ding, C.K., Gallant, M., Gareau, Y., Griffin, P.R., Labelle, M. \& Lazebnik, Y.A. (1995) Identification and inhibition of the ICE/CED-3 protease necessary for mammalian apoptosis. Nature 376, 37-43.

19. Karbowski, M., Spodnik, J.H., Teranishi, M., Wozniak, M., Nishizawa, Y., Usukura, J. \& Wakabayashi, T. (2001) Opposite effects of microtubule-stabilizing and microtubule-destabilizing drugs on biogenesis of mitochondria in mammalian cells. J. Cell Sci. 114, 281-291.

20. Cushman, M., He, H.M., Katzenellenbogen, J.A., Varma, R.K., Hamel, E., Lin, C.M., Ram, S. \& Sachdeva, Y.P. (1997) Synthesis of analogs of 2-methoxyestradiol with enhanced inhibitory effects on tubulin polymerization and cancer cell growth. J. Med. Chem. 40, 2323-2334.

21. Lin, H.L., Liu, T.Y., Chau, G.Y., Lui, W.Y. \& Chi, C.W. (2000) Comparison of 2-methoxyestradiol-induced, docetaxel-induced, and paclitaxel-induced apoptosis in hepatoma cells and its correlation with reactive oxygen species. Cancer 89, 983-994.

22. Hamel, E., Lin, C.M., Flynn, E. \& D’Amato, R.J. (1996) Interactions of 2-methoxyestradiol, an endogenous mammalian metabolite, with unpolymerized tubulin and with tubulin polymers. Biochemistry 35, 1304-1310. 
23. Wang, Z., Yang, D., Mohanakrishnan, A.K., Fanwick, P.E., Nampoothiri, P., Hamel, E. \& Cushman, M. (2000) Synthesis of B-ring homologated estradiol analogues that modulate tubulin polymerization and microtubule stability. J. Med. Chem. 43, 2419-2429.

24. Attalla, H., Makela, T.P., Adlercreutz, H. \& Andersson, L.C. (1996) 2-Methoxyestradiol arrests cells in mitosis without depolymerizing tubulin. Biochem. Biophys. Res. Commun. 228, 467-473.

25. Attalla, H., Westberg, J.A., Andersson, L.C., Adlercreutz, H. \& Makela, T.P. (1998) 2-Methoxyestradiol-induced phosphorylation of Bcl-2: Uncoupling from JNK/SAPK activation. Biochem. Biophys. Res. Commun. 247, 616-619. 